\title{
Legal Aspects of the Right to Nationality Pursuant to Myanmar Citizenship Law
}

\author{
Su Yin Htun \\ University of Mandalay \\ Email: sweetyhtun79@gmail.com
}

\begin{abstract}
It is universally accepted that everyone has the right to citizenship. Myanmar's framework on the right to nationality constitutes a unique, exclusive, ethnic citizenship system based on jus sanguinis, or the law of blood. Myanmar's Citizenship Law was enacted in 1982 by repealing the Union Citizenship Act of 1948. As citizenship parameters were changed by the Law, many people in the Kachin, Karen, and Rakhine states lost their nationality rights and consequently suffered human rights abuses. In the Rakhine state, serious communal violence occurred in 2012, 2016, and 2017, and the government declared a state of emergency. This research paper focuses on how Myanmar can adhere to international standards for nationality rights. It provides a historical overview and legal analysis of citizenship laws in Myanmar using a human rights lens and offers suggestions for legal reforms that can help address the problem of statelessness in Myanmar. Specifically, it recommends the use of the jus soli, or law of the soil, approach to citizenship.
\end{abstract}

Keywords: Nationality, Citizenship, Jus Sanguinis, Jus Soli

\section{INTRODUCTION}

When the right to nationality is legally awarded, a person is normally considered to be a citizen by Constitution, Administrative orders, and specific nationality laws. In the citizenship history of Myanmar, there are three constitutions (1947, 1974 and 2008) and two citizenship laws (1948 and 1982). The current constitution is the 2008 Constitution of the Republic of the Union of Myanmar and the citizenship law is the Union of Burma Citizenship Law of 1982. Myanmar uses the jus sanguinis principle in its present nationality law. When the law changed and political dynamics made some people stateless, the most impacted were the Rohingya people in Rakhine state. There are diverse ethnic populations in Myanmar's Rakhine state, which borders the Bay of Bengal in the west and Bangladesh in the north. This population can be divided into two communities: ethnic groups such as the Rakhine, Kaman, Mro, and Khami on the one side and Rohingya Muslims on the other. Among those populations, the Rohingya have long been a stateless group. They are de jure stateless people who are not considered nationals by the 
Citizenship Law of 1982. They have been impacted by discrimination, inequality, and loss of legal identity. In addition to human rights infractions, sectarian violence in Rakhine state peaked in 2012, 2016, and 2017. Hundreds of thousands of Rohingya people fled from Rakhine State to neighbouring Bangladesh. Their mass exodus called for the world's attention and has become a serious challenge for Myanmar. Realizing the role of statelessness in Myanmar's tense political reality, this paper examines citizenship regulation, human rights abuses, communal violence, and Myanmar's efforts to address these issues.

This research focuses on theories related to nationality rights and legal issues in Myanmar by Laura Van Waas, who primarily explores statelessness' impact on human rights and governments' obligation to protect, prevent, and address statelessness under international treaties and customary international law.' The author also analyses the work of Ko Swan Sik (1990), Philippe Leclerc and Rupert Colville (2007), Alexandra De Mersan (2016) and Kazi Fahmida Farzana (2016), all focusing on the statelessness of Rohingya people. This paper expands upon these authors' findings by arguing that national citizenship law, immigration rules, and weak rule of law contribute to the issue of statelessness. This paper draws on reports of UN charter- and treaty-based bodies, such as the Human Rights Council or Human Rights Committee, which have reviewed Myanmar's human rights situation in their reports and recommendations. Although it has no direct legal effect, there are international pressures to enforce human rights by condemning the particular situation in Myanmar. There is also a report issued by the 2017 Advisory Commission on the Rakhine State (the Annan Commission), which was led by the former, now deceased, UN Secretary-General Kofi Annan. This paper likewise draws upon the Annan Commission's recommendations and identifies additional obstacles to solving human rights issues in Myanmar.

The paper is based on the research questions: (1) to what extent are human and civil rights based on the right to nationality? (2) How can Myanmar's legal framework for citizenship rights be reformed to align with international human rights standards? The aim of this research is to analyse the fundamental human rights related to nationality in Myanmar's national laws, to discuss the issues of citizenship status in impacted border areas, and to seek ways to solve human rights and statelessness issues by point of law. This paper focuses on the legal issues of Rohingya related to their right to nationality by referencing international law and national regulations. This paper uses legal research methods and examines Myanmar's Citizenship Law, customary international law and international human rights law. To complement the article's primary sources-predominantly international, regional, and domestic legal documents-this article also analyses extant academic literature. This research aims to pave the way for reviewing Myanmar's Citizenship Law, such that it is compatible with international human rights standards.

1 Laura van Waas, Nationality Matters: Statelessness Under International Law (Intersentia, 2008). See also Laura van Waas \& Melanie J Khanna, Solving Statelessness (Wolf Legal Publishers (WLP), 2017). 


\section{CITIZENSHIP REGULATIONS IN MYANMAR}

There are two internationally accepted legal principles of citizenship: jus soli and jus sanguinis. The former translates literally to the law of the land or citizenship based on place of birth. The latter dictates that citizenship is based on blood or descent. It generally means that citizenship is awarded to individuals whose parents are a citizen of a given state. Under certain circumstances, the jus sanguinis principle in nationality laws can also produce statelessness in the newborn children of married, non-stateless parents. This section discusses how Myanmar's legal history shapes the parameters of citizenship within the country. ${ }^{2}$

The Republic of the Union of Myanmar was ruled by successive dynasties of monarchs until 1885, during which Yazathat (a royal order in the Burmese monarchical era) provided for criminal law; Dhammat, provided for family tradition and civil law; and Phyathton was a compilation of legal precedents set by judges. After 1885, the whole of Burma fell under the British Empire as a province of British India. The British government enacted different kinds of laws throughout British India, which included what is now India, Pakistan, Bangladesh, Sri Lanka, Bhutan, and Nepal. In 1935, the Government of Burma Act was passed, establishing the territory of Burma as a separate administrative unit within the British Empire. ${ }^{3}$ Then, in 1947, Burmese political leaders drafted the first constitution, which entered into force in January 1948 when Burma became an independent state. ${ }^{4}$

As Burma $a^{5}$ was one of the provinces of India during the British era, residents of British India enjoyed free movement to and from the territory. After the British left Myanmar, many people from India remained in Myanmar as permanent residents. The Constitution of the Union of Burma addressed "citizenship status" in Section 11. Under this provision, a person who is born to any indigenous parents, or by any Burmese citizens, or to parents who have permanently resided in any Burmese territory for a period of no less than eight years during the British era shall be legally considered a citizen of Burma. ${ }^{6}$ The Union Citizenship Act and Union Citizenship Election Act were enacted on January 4, 1948. According to these laws, a permanent resident who continuously stayed in Burma for no less than eight years could obtain a citizenship certificate and be considered a naturalized citizen. Under these laws, any descendant of third generation citizens can be a citizen of the

2 Achiron Marilyn, Nationality and Statelessness: A Handbook for Parliamentarians, (United Nations Human Rights Commissioner for Refugees and Inter-Parliamentary Union, 2005) at 21.

3 Jose Maria Arraiza and Olivier Vonk, Report on Citizenship Law: Myanmar, (Global Citizenship Observatory (GLOBALCIT), RSCAS/GLOBALCIT-CR 2017/14, October 2017), at 6 .

4 Constitution of the Union of Burma 1947 Constituent Assembly of Burma Rangoon, (Supdt, Govt. Printing and Stationery, Burma) 4th January 1948.

5 In 1989, Burma changed its name to Myanmar. I use the terms Burma and Myanmar interchangeably in this paper.

6 Constitution of the Union of Burma, Statute of Myanmar, 1947, c 2, s 11 (QL). 
Union. ${ }^{7}$ In 1949, for the first time, people registered as citizens by the Residents of Myanmar Registration Act, and all citizens were issued the National Registration Card (NRC). ${ }^{8}$

In 1962, the Revolutionary Council that was formed and led by General Ne Win took state power through a coup d'état and subsequently changed the extant political and legal systems. Since that time, the country has been under military rule. The Revolutionary Council drafted and enacted the Socialist Constitution in 1974. The country's name was changed to the "Socialist Republic of the Union of Myanmar" and a socialist legal system was imposed along with a one-party system called the "Burma Socialist Programme Party." The 1974 Constitution, unlike the 1948 Constitution, explicitly defined "citizen." All persons who were born citizens were themselves citizens of the Union, and persons who were vested with citizenship according to existing laws were also citizens. ${ }^{9}$ Citizenship, naturalization, and revocation of citizenship were all prescribed by law. ${ }^{10}$ All citizens were equal before the law irrespective of ethnic status, official position, wealth, culture, religion, or sex." As a result of the new constitution's explicit definition, citizenship in Myanmar was very different under the 1948 and 1974 Constitutions.

The main difference between these two constitutions is that a third generation could not be considered citizens even though their ancestors in the two previous generations had citizenship certificates. In 1982, the Revolutionary Council enacted the new Citizenship Law and repealed the Union Citizenship Act of 1948. According to the 1982 Myanmar Citizenship Law, there are three types of citizenship that can be conferred by the Council of State: ${ }^{12}$ citizen, $^{13}$ associate citizen, ${ }^{14}$ and naturalized citizen. ${ }^{15}$ This Council has the power to decide whether members of any ethnic group can become citizens of any type described above. ${ }^{16}$ By law, Myanmar citizenship is reserved for the eight main ethnic groups: Kachin, Kayah, Karen, Chin, Burmese, Mon, Rakhine or Shan and any ethnic groups contained within those main groups..$^{17}$ A foreigner can never gain citizenship through marriage to a citizen. ${ }^{18}$ The Law stipulates that citizenship can be obtained by descent, through naturalization, or through birth by citizens or naturalized citizens or associated citizens. Section 7 appeals to the jus sanguinis principle, stating that citizenship is for a child whose parents are Burmese citizens, regardless of whether the child is born in or outside of the territory. Similarly, citizenship can

$7 \quad$ Union Citizenship Act, Statute of Myanmar, 1948, c 1, s 4(2) (QL).

8 The Residents of Burma Registration Act 1949 and Residents of Burma Registration Rule 1951.

9 Constitution of the Republic of the Union of Burma, Statute of Myanmar, 1974, c 11, s 145 (QL).

10 Ibid, c 11, s $146(\mathrm{QL})$

11 Ibid, c 11, s 147 (QL).

12 Burma Citizenship Law, Statute of Myanmar, 1982, c 2, s 8 (QL).

13 Ibid, c 1, s 2(b) (QL).

14 Ibid, c 1, s 2(c) (QL).

15 Ibid, c 1, s 2(d) (QL).

16 Ibid, 1982, c 2, s 4 (QL).

17 Ibid, 1982, c 2, s 5 (QL).

18 Ibid, 1982, c 2, s 15 (QL). 
belong to a third generation child born to one citizen, naturalized citizen, or associate citizen and one parent who is the second generation of naturalized or associate citizen parents.

Looking at the Myanmar Citizenship Law, there is discrimination between citizens and associate or naturalized citizens in application procedures, as well as rights and duties. The citizens that are from the eight main ethnic groups ${ }^{19}$ do not have any trouble applying for citizenship. Associate citizens ${ }^{20}$ are citizens determined by the Central Body under the Ministries of Home Affairs, Defense Service, and Foreign Affairs. ${ }^{21}$ Those citizens shall abide by the provision from Sections 23 to 41 . Associate citizens cannot be become a full citizen, even if they marry a full citizen; however, members of a third generation descended from an associate citizen can become a full citizen. ${ }^{22}$ Naturalized citizens are those who have conclusive evidence of their naturalization by the former Union Citizenship Act of $1948 .^{23}$ Sections 43 to 45 provide the qualifications for naturalization, such as family record history, national language proficiency, adult age, good character and good morality. Although the law allows for naturalization of any kind of citizen's foreign spouse, the application for naturalization will be rejected if the husband or wife is dead or divorced before the application is approved. ${ }^{24}$ As the law doesn't allow for dual citizenship, the applicant-whether for associate or naturalized citizens-shall not belong to any other nationality at the time of application and cannot reacquire another country's citizenship if Burmese citizenship has been revoked or rejected. ${ }^{25}$ Furthermore, children lose the right to nationality if their parents fail in applying. ${ }^{26}$

In 1989, the NRCs issued under the 1949 Residents of Burma Registration Act were replaced by three different types of "Citizenship Scrutiny Cards." The new cards were color-coded to facilitate the categorization of the bearer's citizenship status-pink cards for full citizens, blue cards for associate citizens, and green cards for naturalized citizens (there were also other colours, such as brown cards for monks). It became mandatory for all citizens to be registered in the family "household list." ${ }^{27}$ Due to the changes of law and policy, many people, although mostly Rohingya people, lacked identity cards and became stateless.

Although Myanmar is a member of the United Nations Convention on the Rights of the Child (UNCRC), the state declined its provision that "even if a child is illegally deprived of his or her identity, States Parties have to render the appropriate assistance and protection." ${ }^{28}$ The UNCRC requires the contracting States Parties to guarantee the child his or her identity, including nationality, name, and family

19 Ibid, 1982, c 2, s 5 (QL).

20 Ibid, 1982, c 3, s 24 (QL).

21 Ibid, 1982, c 4, s 67 (QL).

22 Ibid, 1982, c 3, s 33 (QL).

23 Ibid, 1982, c 4, s 42 (QL).

24 Ibid, 1982, c 4, s 52 (QL).

25 Ibid, 1982, c 4, s $41 \& 46(\mathrm{QL})$.

26 Ibid, 1982, c 2, s 27 \& 49 (QL). S. of the Burma Citizenship Law, 1982.

27 Myanmar Citizenship Rules 1989

28 Convention on the Rights of the Child, (adopted 20th November 1989, entered into force 2nd September 1990, UNGA Resolution 44/25) (UNCRC), art 8. 
relations. Under Myanmar's 1993 Child Law, a child shall be awarded citizenship in accordance with the provisions of the existing law. ${ }^{29}$ Therefore, any child who is born in the Myanmar territory cannot obtain citizenship if his or her parents are not Myanmar citizens. Myanmar's existing laws are fundamentally based on the jus sanguinis theory of citizenship, or rather, based on an individual's blood lineage.

In summary, the current citizenship law is totally rigid and discriminatory between three kinds of citizens: full citizen, naturalized citizen, and associate citizen. A third generation descended from a first generation recognized as naturalized or associate citizens could previously apply for citizenship in the 1980s, but Myanmar's political dynamic has since changed dramatically. As the result of the changes in the definition of citizenship vis-a-vis changes in core legal documents, many ethnic minority members have been deprived of their citizenship. Furthermore, other ethnic groups, excluding the Rohingya, have not been forcibly moved from the country even though they similarly do not enjoy the right to nationality. The Rohingya people have been not only deprived of their nationality, but also experienced grave violence resulting in mass exodus as a result of their noncitizenship. Changes in the parameters of citizenship in Myanmar's constitutional law have directly made the Rohingya people a stateless people.

\section{DEPRIVATION OF RIGHTS TO NATIONALITY}

After the 1974 Constitution, third generation descendants of associate citizens and naturalized citizens in Kachin, Shan, Karen, and Rakhine states were deprived of citizenship and became stateless. Kachin lies close to China, the Shan and Karen States are near to Thailand and the Rakhine State borders to Bangladesh. Among those, the most highly impacted area is the Rakhine state. In Bangladesh in 1970, there was a nine-month long Bangladesh Liberation War for independence from Pakistan. As a result of this war, many people fled to neighbouring countries as refugees. At that time, there were about more than a million of Rohingya people in Rakhine. In the meantime, there were more than ten million war refugees on Indian land. Although India responded to its refugee situation with the help of international organizations, Myanmar did not cooperate with international organizations and built an isolated nation. ${ }^{30}$ In 1978, the government created the "Naga Min (Dragon King) Operation," a census conducted by security authorities inter alia to identify illegal migrants in border regions such as Kachin, Shan and Rakhine and other entry points (e.g., ports in Mon and Rangoon). In 1978, the Naga Min Operation led to a mass forced removal of thousands of Muslims from

29 Myanmar Child Law, Statute of Myanmar, 1993, c 5, s 10 (QL).

30 Khin $\mathrm{Mg}$ Saw, Geopolitical of the Powers and Bengali Problems in Burma, http://www.burmalibrary.org/docs21/Khin-Maung-Saw-NM-2014Geopolitics_of_the_Powers _and_the_Bengali-Problems_in-Burma -en.pdf 
Rakhine across the border to the recently independent Bangladesh, entirely without distinguishing who was from Myanmar and who was from Bangladesh. ${ }^{31}$

The result of this operation was the displacement, over the Bangladeshi border (and specifically into the Cox's Bazar region), of over 220,000 Rohingyas. In October 1978, a meeting between representatives of Myanmar and Bangladesh took place at a re-integration camp, where the two countries signed an agreement on the repatriation of refugees to Myanmar. Beginning on 15 October 1978, a fresh initiative called the "Hintha" Campaign established new villages and provided lands to the returnees. In 1991, a cyclone hit Bangladesh and Myanmar and displaced many individuals. In response to the cyclone, the Myanmar State Law and Order Restoration Council (SLORC) undertook the Pyi Thar Yar Operation. These operations claimed to enforce border security and while forcibly displacing Rohingya people who were deprived their nationality. In the meantime, UNHCR intervened and convinced the Myanmar government to allow for the repatriation of more than 250,000 refugees who fled to Bangladesh in 1991 and 1992. This was one instance of successful cooperation between UNHCR and Myanmar with respect to the rights of displaced persons.

\section{THE IMPACT OF RIGHT TO NATIONALITY ON HUMAN RIGHTS}

As mentioned above, the Rohingya people are denied their nationality rights by changes in core laws and political leadership. As of 2017, there are total numbers of 894,733 persons of concern in Myanmar according to UNHCR statistics. ${ }^{32}$ Almost all of those accounted for by this number belong to the Rohingya people, who do not currently enjoy the legal guarantee of nationality.

\section{Right to Nationality}

The right to nationality was articulated in the 1948 Universal Declaration of Human Rights (UDHR): "everyone has the right to a nationality, and no one shall be arbitrarily deprived of his nationality nor denied the right to change his nationality." ${ }^{33}$ After UDHR, two conventions emerged to resolve and prevent

31 Jose Maria Arraiza and Olivier Vonk, Report on Citizenship Law: Myanmar, (Global Citizenship Observatory (GLOBALCIT), RSCAS/GLOBALCIT-CR 2017/14, October 2017), at 7 .

32 Persons of concerns are refugees, asylum seekers, returned refugees, internally displaced persons (IDPs), returned IDPs and stateless persons. UNHCR Statistics News Online, $<$ http://popstats.unhcr.org/en/overview\#_ $\mathrm{ga}=2.101980231 .771169173 .1542142531$ $280153828.1541856827>$

33 Universal Declaration of Human Rights, (ratified 10th December 1948, UNGA Resolution 217 A) (UDHR) art 15. 
statelessness. The 1954 Convention relating to the Status of Stateless Persons provided a basic outline of human rights for stateless people. The 1961 Convention on the Reduction of Statelessness attempted to further prevent statelessness by establishing an international framework to ensure the right of every person to a nationality. In addition to these two conventions, the international community sought to establish safeguards in nationality laws to prevent statelessness at birth as well as later in life. Article 9 of the 1979 Convention on the Elimination of All Forms of Discrimination Against Women (CEDAW), Article 7 of the 1989 Convention on the Rights of the Child (CRC) and Article 18 of the 2006 Convention on the Rights of Persons with Disabilities (CRPD) affirmatively state that the right to nationality should be granted after birth. The right to nationality is found not only in international agreements, but also in regional conventions and declarations such as the 2013 ASEAN Human Rights Declaration (AHRD). Based on international and regional law together, it is certain that arbitrary deprivation of nationality is internationally prohibited.

\section{Child Rights}

Many of the Rohingya people displaced from Myanmar to Bangladesh are children. Lack of respect for children's rights may also contribute to the Rohingya people's statelessness. In particular, the failure to ensure every child's right to birth registration-protected, for instance, by CRC Article 7-may be problematic. Article 25 (2) of UDHR states that motherhood and childhood are entitled to special care and assistance, and that children born in or out of wedlock must receive equal social protection. CRC provides for the best interest of the child ${ }^{34}$ by defending children's due consideration in judicial and administrative decisions, as well as in other actions such as the enactment of laws, policies, strategies, programmes, plans, and guidelines. ${ }^{35}$ There are many provisions for children's rights in Myanmar's 1993 Child Law. ${ }^{36}$ Yet these rights are awarded only to children acknowledged as Myanmar nationals. A child's nationality is provided for in Section 10 of the Child Law, which states that every child shall have the right to citizenship in accordance with the provisions of the existing law. Rohingya children, who are not acknowledged by the state constitution or Child Law, can neither obtain citizenship nor protection.

34 Convention on the Rights of the Child, (adopted 20th November 1989, entered into force 2nd September 1990, UNGA Resolution 44/25) (UNCRC), art 3.

35 General Comment 14 of the Convention on the Rights of the Child, (adopted 14th January 1st February 2013, published 29th May 2013, CRC /C/GC/14, para 2 A.

36 Myanmar Child Law, State Law and Order Restoration Council Law No. 9/9, 14th July 1993. 


\section{Women's Rights}

Rohingya women endure both fundamental rights abuses and sexual violence. Although Myanmar acceded to CEDAW, there is no specific national level law to protect women's rights or prevent violence against women. In 2017, the government took several significant steps to address women's rights, such as drafting a law on prevention of violence against women for submission to parliament, implementing a national strategic plan for the advancement of women, and establishing a genderbased violence hotline. ${ }^{37}$ Rohingya women could not enjoy rights such the right to work or equal employment opportunity, social security, the protection of health care, bank loans, or recreation and sports, all of which are mentioned in CEDAW ${ }^{38}$ In UN Human Rights Council Resolution S-27/1 of 5 December 2017, the special rapporteur expressed concern towards the widespread violence against women in Myanmar, including rape, gang rape and other forms of sexual violence, killings, and other violent attacks. ${ }^{39}$ In Myanmar, violence against women is not only perpetrated against Rohingya women, but also other ethnic minority groups in the Rakhine state. Rohingya women are not considered Myanmar nationals and as such do not necessarily enjoy the same rights as other women, even though they may also face gender-based violence and discrimination.

\section{Internal Freedom of Movement}

Article 13 of UDHR states that everyone shall have the right to freedom of movement and residence within the borders of each state. In Myanmar, the Rohingya's freedom of movement is severely restricted. They are virtually confined to their respective villages, unable to access medical and educational services, due, inter alia, to the fact that should they wish to travel outside their respective villages, they would require official authorization and must pay a fee which is in many cases unaffordable. This restriction, which is not applied to the Rakhine population in Rakhine State, significantly diminishes the Rohingya's standard of living, particularly regarding food security. When Rohingya people do attempt to travel without authorization, if apprehended, they are arrested and imprisoned. ${ }^{40}$

Both Rohingya and Rakhine people in northern Rakhine face restrictions on movement, which includes access to farmland, fishing areas, and markets. While formal restrictions, such as legal orders, are more prevalent, informal and social

37 Report of the Secretary-General on Conflict-Related Sexual Violence, (published 23rd March 2018) S/2018/250, para 28.

38 Convention on the Elimination of all forms of Discrimination Against Women, (adopted 18th December 1979, entered into force on 3rd September 1981) (CEDAW) (GA Resolution 34/180) art 11-13.

39 Situation of human rights of Rohingya Muslims and other minorities in Myanmar, Special Rapporteur Resolution S-27/1, (adopted 5th December 2017), A/HRC/RES/S-27/1, para 6.

40 Laura Van Waas, Nationality Matters; Statelessness under International Law, (Intersentia, 2008), at 242. 
restrictions constitute the main barrier to movement in central and southern parts of the Myanmar. ${ }^{41}$ Travel between villages, townships and outside the Rakhine state has long been restricted for Rohingya people on the basis of a discriminatory travel authorization system. Travel restrictions have serious consequences on economic, social and cultural rights, including the right to food, health, and education. ${ }^{42}$

Due to the attacks in the Rakhine state, any person must now show an ID card for internal travel. Anyone travelling must hold a NVC in accordance with the 1982 Citizenship Law, 1949 Myanmar Citizens Registration Act and the 1949 Registration of Residents in the Union of Myanmar Act. ${ }^{13}$ As a form of advocacy for acquiring and holding NVCs, members of the Committee for Implementation of the Recommendations on Rakhine State have attempted to issue the NVCs and even held briefing meetings with Muslim village administrators, 100 household heads, and local people in northern Rakhine State. As of December 31, 2017, only 5,162 NVCs had been issued. ${ }^{4}$ Myanmar authorities urged refugees to accept the NVCs, apply for citizenship, and become citizens. The Union Minister of Social Welfare, Relief and Resettlement stated that returned refugees would have the freedom to legally travel in Maungtaw District, and students would be able to enroll in universities when they have received their NVC. ${ }^{45}$ However, no Rohingya students have been documented in Sittwe University or other universities in Myanmar.

\section{Legal Rights}

In the context of this article, personhood implies factual existence and legal personality implies legal existence. Legal personality is required for an individual to be recognized as a bearer of rights and duties. As such, legal personality is a basic requirement for the capacity to engage in various legal transactions, including contracting marriage, purchasing, selling or inheriting property or staking a claim in court. $^{46}$ If someone robs or rapes someone whose legal personality is not acknowledged, they may find that they cannot lodge a complaint because they do not legally exist and police require proof of existence before opening an

41 Advisory Commission on Rakhine State, Towards a Peaceful, Fair and Prosperous Future for the People of Rakhine: Final Report of the Advisory Commission on Rakhine State, (published August 2017) at 33.

42 Independent International Fact-Finding Mission on Myanmar, Report of the detailed findings of the Independent Fact-Finding Mission on Myanmar, (published 17th September 2018, A/HRC/39/CRP .2), at 6.

43 National Verification Card-NVC process stepped up in Maungtaw, Headline News, Global New Light of Myanmar, (Volume 4, No.204, 7th November 2017), at 6, <www.globalnewlightofmyanmar.com>.

44 Report of the People on the Progress of Implementation of the Recommendations on Rakhine State, President's Office News Online, Myanmar President's Office, <http://www.presidentoffice.gov.mm/en/?q=issues/rakhine-state-affairs/id-8457>

45 Dr Win Myat Aye, U Nyi Pu, Japanese Ambassador discuss Rakhine State, President's Office News Online, Myanmar President's Office, <http://www.presidentoffice.gov.mm/en/?q=issues/rakhine-state-affairs/id-8815>

46 Laura Van Waas, Nationality Matters; Statelessness under International Law, (Intersentia, 2008), at 262. 
investigation. ${ }^{47}$ Article 6 of UDHR provides for universal legal rights, stating that everyone has the "right to recognition everywhere as a person before the law." Article 16 of the International Covenant on Civil and Political Rights (ICCPR) builds upon UDHR's guarantee of legal rights by establishing the non-derogation of rights. ${ }^{48}$

In addition to the above rights, hundreds of thousands of Rohingya people fled from Rakhine to Cox's Bazar in Bangladesh without shelter, food, or water. They walked for days or weeks across forests and mountains. The human rights violations they suffered are already prohibited in international human rights conventions and customary international law. The Rohingya are unable to enjoy their fundamental human rights, such as registration of birth, marriage, and death memorandums. The violation of these fundamental rights, or rather failure to uphold them, complicates the state's ability to record the Rohingya population and which has dramatically increased because the state cannot record it. Statelessness of the Rohingya people has created space for human rights and security crises and violations, all of which do not comply with international human rights norms.

\section{COMMUNAL VIOLENCE IN RAKHINE STATE}

From May to October 2012, sectarian conflict between the Rakhine ethnic group and Rohingya people flared in northern Rakhine. The rape of an ethnic Rakhine woman by three Muslim men sparked the violence, resulting in tragedies for both communities. Both communities attacked each other by setting fire to and killing many people in Yathedaung, Kyauktaw, Pauktaw, Sittway, Mrauk-U, Kyaukphyu and Yanbye. The government reported that 58 ethnic Rakhine people and 134 Rohingya were killed while 265 suffered injuries in total. 7,422 Rohingya homes and 1,192 ethnic Rakhine homes were destroyed. ${ }^{49}$ In terms of human casualties, the Rohingya were more affected than the ethnic Rakhine community. Human Rights Watch (HRW) released satellite images revealing 35 acres of destruction-including hundreds of buildings and houseboats, all ravaged by fire-and showing the widespread attack targeted areas with a significant Rohingya population. $^{50}$

Due to communal violence, a state of emergency was declared on June 10, 2012 under Section 144 of Myanmar's Criminal Procedure Code. Myanmar Defense Services (Tatmadaw) undertook security operations to rescue victims and restore stability in the impacted areas, as the Constitution renders it the power to

47 Philippe Leclerc and Rupert Colville, In the Shadows, Millions seek to escape the grim world of the stateless, (Refuggees Magazine, No.147, Issue 3 of 2007), at 6.

48 International Covenant on Civil and Political Rights, 19 December 1966, 999 UNTS 171, Can TS 1976 No 47 (entered into force 23 March 1976) (ICCPR), art 4.

49 Final Report of Rakhine Inquiry Commission on Sectarian Violence in Rakhine State, (Republic of the Union of Myanmar) (published 8th July 2013) at 18 -21.

50 Burma: Satellites Images Show Widespread Attacks on Rohingya, Human Rights Watch News Online, (2012), https:/www.hrw.org/news/2012/11/17/burma-satellite-images-show-widespreadattacks-rohingya 
assist citizens when calamities affect the Union. ${ }^{51}$ The Tatmadaw subsequently implemented measures to increase security in places where violence had previously broken out. From October 27, 2012 onwards, the Tatmadaw had the power to command the security operations in troubled areas. ${ }^{52}$ However, in January 2014, the UN High Commissioner for Human Rights, Navi Pillay, received credible information of the killing of 48 Rohingya in two incidents on the $9^{\text {th }}$ and $13^{\text {th }}$ of January 2014 and demanded the government investigate. ${ }^{53}$ The government of Myanmar established a panel of 10 members to investigate the January 2014 incident. Myanmar's National Human Rights Commission concluded that there was no evidence to prove the reported incidents of violence. ${ }^{54}$

Myanmar's political status changed to a civilian government led by the National League for Democracy party (NLD) after a landslide victory in the 2015 general election. In the civilian government's first year, an ethnic Rakhine armed group formed the Arakan Army (AA) and started operating in the Rakhine state with the aim of self-determination for ethnic Rakhine (Arakanese) people, safeguarding cultural heritage, and promoting "national dignity and Arakanese national interest. ${ }^{{ }^{5} 5}$ The AA was formed under the umbrella of the Kachin Independence Army (KIA) by Rakhine migrant laborers in the jade mining complex of Hpakant, later on emerging as a force of nearly 2,000 combatants backed by a trained reserve. ${ }^{56}$

In June 2016, the Arakan Rohingya Salvation Army (ARSA) materialized in northern Rakhine. In the meantime, the Myanmar Government formed the Advisory Commission on the Rakhine State. The Commission, composed of six national and three international members, was chaired by former United Nations Secretary-General Kofi Annan. Its mandate was to find "lasting solutions to the complex and delicate issues in Rakhine State, in accordance with established international standards." ${ }^{, 57}$ On October 9, 2016, an armed group attacked the Maungdaw and Yathedaung townships with knives, slingshots and about 30 arms

51 Constitution of the Republic of the Union of Myanmar, Statute of Myanmar, 2008, c 7, s 342 (QL).

52 Final Report of Rakhine Inquiry Commission on Sectarian Violence in Rakhine State, (Republic of the Union of Myanmar) (published 8th July 2013) at 18 -28.

53 Top UN officials call for probe into latest violence in Myanmar's Rakhine state, (UN News Centre News Online, (2014). Retrieved March 15, 2014, <http:// www.un.org/apps/news/story>.

54 Thin Thiri; Myanmar President orders Commissions to probe Rakhine Violence, Radio Free Asia News Online, <https:/www.rfa.org/english/news/myanmar/rakhine02072014181601.html>

55 Independent International Fact-Finding Mission on Myanmar, Report of the detailed findings of the Independent Fact-Finding Mission on Myanmar, (published 17th September 2018, A/HRC/39/CRP .2), at 101.

56 Anthony Davis, Myanmar's other Rakhine Problem, Asia Time News Online, November 29 2017, <http://www.atimes.com/article/myanmars-rakhine-problem/>

57 Independent International Fact-Finding Mission on Myanmar, Report of the detailed findings of the Independent Fact-Finding Mission on Myanmar, (published 17th September 2018, $\mathrm{A} / \mathrm{HRC} / 39 / \mathrm{CRP} .2)$, at 101 . 
and ammunitions ${ }^{58}$ On that day, the Tatmadaw asked permission from the President's Office to carry out a military operation in the Buthidaung, Maungtaw and Yathedaung townships, which was granted by the government ${ }^{59}$

On August 25, 2017, two days after the Annan Commission's report was released, ARSA launched coordinated attacks on a military base and up to 30 security force outposts across northern Rakhine. The security forces' response was immediate, brutal, and grossly disproportionate.60 Myanmar's Central AntiTerrorism Committee declared ARSA a terrorist group on August 25, 2017 according to the Section 73(b) of Myanmar's 2014 Counter-Terrorism Law.61 The Tatmadaw engaged in counter-terrorism measures in northern Maungdaw, Buthidaung-Taungbazar, Alethankyaw-Koetankauk and Chwitpyin-Zaydipyin in cooperation with the Myanmar police force, border guard police, and Arakanese villagers. 62 The operations lasted for two months, wherein more than 40 percent of all villages in northern Rakhine state were partially or totally destroyed. During the course of the conflict, people from all local communities were killed; Hindu, Rakhine, and Rohingya people alike. Over 725,000 Rohingya people fled to Bangladesh by September $2018 .^{63}$

\section{REGIONAL AND INTERNATIONAL INTERVENTION}

Myanmar has played a pivotal role in international society, at the very least since its independence, if not long before. Myanmar has ratified and acceded to the major human rights conventions; the United Nations Charter; the Rome Statute, establishing the International Court of Justice; the Convention on the Prevention and Punishment of the Crimes of Genocide; the four 1949 Geneva Conventions; the Convention on the Rights of the Child; the International Covenant on Economic, Social and Cultural Rights; the Convention on the Elimination of all forms of Discrimination against Women; and the Convention on the Rights of the Persons with Disabilities. It seems as though Myanmar, as an international entity, is obligated to follow international law and UN recommendations.

58 Report of International Crisis Group, Asia News Agency, 21st December 2016, <https://www.crisisgroup.org /asia/south-east-asia/myanmar/283-myanmar-new-musliminsurgency-rakhine-state>

59 Myanmar Politics and Tatmadaw, Part I, (Directorate of Public Relations and Psychological Warfare Publishing, July 2018), at 32.

60 Independent International Fact-Finding Mission on Myanmar, Report of the detailed findings of the Independent Fact-Finding Mission on Myanmar, (published 17th September 2018, $\mathrm{A} / \mathrm{HRC} / 39 / \mathrm{CRP} .2)$, at 179 .

61 Order No.1/2017, The Republic of the Union of Myanmar Anti-terrorist Central Committee, (issued 25th August 2017) Global New light of Myanmar, Volume IV, Number 131, 26 Saturday, August, 2017, at 1.

62 Myanmar Politics and Tatmadaw, Part I, (Directorate of Public Relations and Psychological Warfare Publishing, July 2018), at 50.

63 Independent International Fact-Finding Mission on Myanmar, Report of the detailed findings of the Independent Fact-Finding Mission on Myanmar, (published 17th September 2018, $\mathrm{A} / \mathrm{HRC} / 39 / \mathrm{CRP} .2)$, at 179 . 
The UN has been watching the human rights situation in Myanmar since 1992; the Commission on Human Rights decided to nominate a Special Rapporteur to establish direct contact with the government and people of Myanmar through Resolution 1992/58. ${ }^{64}$ Since then, the Commission has urged Myanmar's government to ensure free access for the Special Rapporteur to any person in the country with whom it is appropriate and within the Special Rapporteur's mandate to meet. Every year, the UN examines and discusses the situation of human rights in Myanmar, while the state usually submits reports to concerned human rights commissions, such as the Women's Rights Commission and the Children's Rights Commission. Concerning reports on human rights, Myanmar considers the Universal Periodic Review (UPR) the most reliable mechanism for assessing human rights issues equally within and among UN member states. ${ }^{65}$ The Myanmar Working Group on the UPR was established in accordance with Human Rights Council resolution 5/1 of June 18, 2007.

The first cycle of the Universal Periodic Review (UPR/2008-2011) on Myanmar was conducted at the $10^{\text {th }}$ session in 2010. From the UPR's second cycle (2012-2016), the Myanmar government received 281 recommendations from 93 countries; however, the state did not accept all recommendations. 115 recommendations, particularly for Rohingya-related issues, are not acknowledged. ${ }^{66}$ For the third cycle (2017-2021), the state produced a mid-term report in February 2018 prepared by the Burma/Myanmar UPR Forum and Equality Myanmar. Myanmar has to finish a final report of the third cycle on July 20, 2020 and receive reviews at the $37^{\text {th }}$ session in fall of $2020 .{ }^{67}$ By analyzing UPR human rights reports, it is found that Myanmar is unwilling to revise the Citizenship Law and admit to human rights violations against the Rohingya people. The UN Security Council issued a statement that the widespread violence in Rakhine State on August 25, 2017 led to the mass exodus of more than 607,000 people belonging to the Rohingya community. ${ }^{68}$

On March 24, 2017, the Human Rights Council established the Independent International Fact-Finding Mission on Myanmar through Resolution 34/22. On August 27, 2018, the UN-mandated Fact-Finding Mission's three experts issued a report documenting Myanmar security forces' abuses against the Rohingya population-including, but not limited to, murder, rape, and torture-and concluded that they amounted to crimes against humanity and war crimes. It is also found that systematic oppression and discrimination amounted to persecution and

64 Situations of Human Rights in Myanmar, Commission on Human Rights Resolution 1992/58, E/CN.4/RES/1992/58, < http://www.securitycouncilreport.org/atf/cf/\%7B65BFCF9B-6D274E9C-8CD3-CF6E4FF96FF9\%7D/Myan\%20E\%20CN4\%20RES\%201992\%2058.pdf >

65 Myanmar National Report for second cycle of Universal Periodic Report, Human Rights Council Resolution 16/21, (published 5th August 2015, A/HRC/WG.6/23/MMR/1, para 96.

66 The Lutheran World Federation, An Analysis of Recommendations, UN Human Rights Council, Universal Periodic Review 2nd Cycle, 23rd Session Myanmar, April 2016, at 16.

67 Meeting Highlights for 23rd Session, United Nations Human Rights Council News Online, <https://www.ohchr.org/EN/HRBodies/UPR/Pages/MeetingsHighlightsSession23.aspx>

68 Statements made by the President of the Security Council in 2017, <www.un.org/en/sc/documents/statements /2017.shtml> 
potentially apartheid. The report also detailed abuses committed by militants and called for them to be held to account. ${ }^{69}$ The Third Committee of the UN General Assembly drafted a resolution on November 16, 2018 to form the "Ongoing Independent Mechanisms that involved 62 members with US $\$ 27$ million” by a recorded vote of 142 in favor, 10 against, and 26 abstentions. ${ }^{70}$ Regarding statelessness of the Rohingya people, ASEAN upholds a non-interference policy, although some Muslim majority countries, such as Malaysia and Indonesia, made a stand to protect the Rohingya people by saying that the crisis was a regional issue. Malaysia criticised other states for failing to condemn Myanmar's treatment of the Rohingya. In 2016, Malaysian Prime Minister Najib Razak claimed that the "world cannot sit by and watch genocide taking place." ${ }^{\text {"71 }}$ However, there were no provisions for either reconciliation or repatriation of the Rohingya people in the last ASEAN Summit statement, made in November $2018 .^{72}$

In summary, the special Rapporteur, Fact-finding Mission and UNHCR requested to inquire about and research the situation of human rights in Myanmar and to bring perpetrators to justice in the International Criminal Court. The international community emphasizes human rights violations, whereas the Myanmar government refuses to admit to or acknowledge such allegations. According to this different opinion, the international community needs to cooperate by fully understanding how to work with the Myanmar government for the future prosperity of the Rakhine state and Rohingya people. This paper argues that the international community, including the UN Human Rights Council and the Myanmar government, are not fully striving to solve the issue of statelessness, but rather maintaining a limited focus on accountability for recent violent events.

\section{MYANMAR'S RESPONSES TO THE ROHINGYA CRISIS}

On August 17, 2012, President U Thein Sein established the 27 member Rakhine Commission of Inquiry by issuing a Presidential Executive Order. ${ }^{73}$ The Commission released its report on July 8, 2013 (Inquiry Commission on Sectarian Violence in Rakhine State, 2013). In the report, there are many recommendations, including a consideration of citizenship claims for Rohingya people through a transparent and accountable process. ${ }^{74}$ As a result of the 2015 State Election, the

69 Independent International Fact-Finding Mission on Myanmar, Report of the detailed findings of the Independent Fact-Finding Mission on Myanmar, (published 17th September 2018, A/HRC/39/CRP .2), at 179 .

70 Resolution of UN General Assembly Third Committee, 73rd Session, 16th November 2018, A/C.3?73/L.51.

71 'Malaysia PM urges world to act against "genocide" of Myanmar's Rohingya', The Guardian, 4 December 2016 http://bit.ly/MalaysiaPM-Rohingya-Dec14

72 Chairman's Statement of the 33rd ASEAN Summit, Singapore, (ASEAN News Online, 13th November 2018), < https://asean.org/chairmans-statement-33rd-asean-summit/> .

73 Notification No.58/2012 by Myanmar President's Office on 17th August 2012

74 Final Report of Rakhine Inquiry Commission on Sectarian Violence in Rakhine State, (Republic of the Union of Myanmar) (published 8th July 2013) at Appendix D. 
country's political status once again changed, and the people of Myanmar are now subject to a nominally civilian government led by the NLD.

On May 30, 2016, the Working Committees on the Implementation of Peace, Stability, and Development of Rakhine State were formed by Notification No. 24/2016. ${ }^{75}$ A Central Committee for the Implementation of Peace and Development in Rakhine State was formed with the State Counselor, Aung San Suu Kyi, as chairperson. The central committee included 20 cabinet ministers, according to an announcement from the President's Office. Concurrently, the President's Office announced the formation of four working committees to assist the central committee in successfully implementing peace, stability and development: (1) Security, Peace and Stability and the Rule of Law Working Committee; (2) Immigration and Citizenship Scrutinizing Working Committee; (3) Settlement and Socio-economic Development Working Committee; and (4) Working Committee on Cooperation with UN Agencies and International Organizations. ${ }^{76}$ In October 2016, the 13 member Rakhine State Investigation Commission was formed by the government. The commission furnished a final report to the Rakhine state legislature in two months, on December 26, 2016. The report mentioned fights and clashes caused by political and security abuses and called for better security both within ethnic Rakhine communities and Rohingya communities beside the Naf River, which flows between Myanmar and Bangladesh.

Soon after, there was increased regional and international pressure on and scrutiny of the Myanmar government's response to the Rohingya crisis. At Malaysia's request, the state called the special informal meeting with ASEAN foreign ministers in December 2016 to discuss the situation. ${ }^{77}$ Through the constructive engagement of the ASEAN members, the Annan Commission was founded as a neutral and impartial body in order to propose concrete measures for improving the welfare of all in the Rakhine state. The final report, released in September 2017, addresses in-depth a broad range of structural issues impeding peace and prosperity in the Rakhine state by supporting several recommendations. The report is the result of 150 consultations and meetings held by the Advisory Commission since its launch. Commission members travelled extensively throughout Rakhine and held meetings in Yangon and Naypyidaw, Indonesia, Thailand, Bangladesh, and Geneva. ${ }^{78}$

On December 1, 2016, the Myanmar government formed the National Investigation Commission on Maungdaw in Rakhine to investigate communal

75 Formation of Working Committee on Implementation of Peace, Stability and Development of Rakhine State, Notification 24/2016 by Myanmar President's Office on 31st May 2016, < http://www.president-office.gov.mm/en/?q=briefing-room/notifications/2016/06/01/id-6380 >.

76 Govt forms committee to implement peace, stability, development in Rakhine State, Global New Light of Myanmar Headline News, June 1st 2016. < http://www.burmalibrary.org/docs22/GNLM2016-06-01-red.pdf .

77 Irrawaddy News, Moe Myint, "ASEAN foreign ministers pledged aid to Arakan state", https:/www.irrawaddy.com/news/burma/asean-foreign-ministers-pledge-aid-to-arakan-state.html

78 Advisory Commission on Rakhine State, Towards a Peaceful, Fair and Prosperous Future for the People of Rakhine: Final Report of the Advisory Commission on Rakhine State, (published August 2017), http://www.rakhinecommission.org/the-final-report/ 
violence in the state, including "whether outside allegations made in connection to area clearance operations undertaken by security personnel are true," and to report by January 31, 2017. The 13 member commission was headed by Vice-President Myint Swe, and its composition and mandate raised serious doubts that it would conduct a thorough and impartial investigation into alleged abuses. The Myanmar military announced that there was a team to investigate whether soldiers operated "within the framework of law" and "to ensure that security forces stay away from using excessive force and committing human rights violations." That investigation commission issued a statement that whoever commits any directives will be met with legal action. The Tatmadaw published its findings on May 23, 2017, reporting that there was no wrongdoing except in two minor incidents. ${ }^{79}$ The report acknowledged the difference in perspectives between Myanmar and international society.

The Committee for the Implementation of the Recommendations on Rakhine State was established on September 12, 2017. ${ }^{80}$ The Committee's purpose is to implement the recommendations of the Annan Commission and Maungdaw Commission. To this end, 10 members were appointed with chairmanship held by the Union Minister of the Ministry of Social Welfare, Relief and Resettlement in September and members were increased in October. ${ }^{81}$ The Union Enterprise for Humanitarian Assistance, Resettlement and Development in Rakhine (UEHRD) was established in October 2017..$^{82}$ The State Counselor said her government had "already implemented" 81 of 88 recommendations made by the Annan Commission, with only long-term issues such as citizenship left to undertake. ${ }^{83}$ There are nine task forces under UEHRD which are focus solely on development in the Rakhine state. ${ }^{84}$

The Myanmar government has also created two multi-national bodies to provide recommendations for long-term solutions to problems in Rakhine. On December 14, 2017, the Advisory Board for the Committee for the Implementation of the Recommendations on Rakhine State was established. The Office of the State Counselor announced that the commission would be headed by

79 https://www.irrawaddy.com/news/burma/burma-army-forms-team-to-investigate-allegations-ofabuse-in-arakan-state.html

80 Establishment of Committee for Implementation of the Recommendations in Rakhine State, Order No.75/2017, President's Office, 12th September 2017, < http://www.presidentoffice.gov.mm/en/?q=briefing-room/orders/2017/10/12/id-7748 >.

81 Establishment of Committee for Implementation of the Recommendations in Rakhine State, Order No.83/2017, President's Office, 9th October 2017, < http://www.globalnewlightofmyanmar.com/republic-union-myanmar-office-president-order-no$832017 />$.

82 Establishment of the Committee for the Union Enterprise for humanitarian Assistance, Resettlement and Development in Rakhine, Order 86/2017 by the Office of the President on October 17 2017, office.gov.mm/en/?q=briefing-room/news/2017/10/19/id-7787

83 Oliver Slow, Two months after MOU signing, UN urges tangible progress in Rakhine, Frontier Myanmar News Oline, <https://frontiermyanmar.net/en/two-months-after-mou-signing-unurges-tangible-progress-in-rakhine $>$.

84 http://rakhine.unionenterprise.org/latest-news-en 
Dr. Surakiart Sathirathai, a veteran Thai diplomat, and include four other international members and five domestic members. ${ }^{85}$ Although one of the international members eventually left, the Advisory Board issued its final report "Report to the People on the Progress of the Implementation of Recommendations on Rakhine State (January to April 2018)” on August 16, 2018.

The Myanmar government established the "independent" Commission of Enquiry with one "international personality" on July 30, 2018 to address reconciliation, peace, stability and development in Rakhine state. This Commission was led by a former Philippine ambassador, Rosario Manalo, together with Japanese diplomat Kenzo Oshima and Myanmar officials Dr. Aung Tun Thet and lawyer U Mya Thein. ${ }^{86}$ The Myanmar government's own descriptions of the commission make clear that its primary purpose is to deflect pressure from the international community.

In addition to the establishment of commissions and committees, Myanmar and Bangladesh signed an agreement for the voluntary return of Rohingya refugees in November 2017. Myanmar also signed a memorandum of understanding (MOU) with UNHCR and UNDP on June 6, 2018 for the repatriation of Rohingya people. In a concerted effort to solve issues in the Rakhine state, the Myanmar State Counselor took responsibilities as chairperson in most of the commissions. The Ministry of Social Welfare, Relief, and Resettlement (MSWRR) is responsible for aiding humanitarian assistance and communications with international organizations and the Rohingya people. However, it is found that the Ministry shows weakness in protecting Rohingya people and a lack of legal discussion in the Myanmar Parliament. The government of Myanmar holds a responsibility to protect its population; however, the government's treatment of the Rohingya is far from fulfilling international standards.

\section{CONCLUSION}

Statelessness in Myanmar is a product of the national Citizenship Law. Until and unless the root cause of statelessness is addressed, problems such as communal violence will continue unresolved. This paper recommends two options to overcome the issue of statelessness in Myanmar. The first option is to revise the Citizenship Law, i.e, the law should embrace the principle of jus soli. Such a change will eliminate statelessness by enabling the acquisition of nationality, usually of the country within which stateless people have the strongest ties. If the principle of jus soli is enshrined in a revised Citizenship Law, issues of statelessness will disappear in future generations. If the law is not changed, the stateless population will steadily

85 Establishment of the Advisory Board for the Committee for Implementation of the Recommendations on Rakhine State, Ministry of the Office of State Counsellor, Global New Light of Myanmar, Friday, 15 December 2017, P-6, Vol IV, No.242, <www.globalnewlightofmyanmar.com >.

86 Establishment of the Independent Commission of Inquiry, Press release 8/2018 by the Office of the President, President Office News Online 30th July 2018, < http://www.presidentoffice.gov.mm/en/?q=briefing-room/statements-and-releases/2018/07/30/id-8914 . 
and dramatically increase. That being said, there remain difficulties in granting citizenship to the Rohingya people. Even the name "Rohingya" is still sensitive in Myanmar. On behalf of the state and society, there would remain obstacles in awarding nationality to the Rohingya people.

The second option is to amend the Child Law to include jus soli. This would be the solution of statelessness for future generations that is referred to in CRC provisions requiring the acquisition of citizenship as soon as possible after birth. If the Myanmar Child Law grants citizenship to a child who is born in Myanmar territory, all children will enjoy equal protections and be considered subject to the best interests of the child according to UNCRC. Even if the Rohingya are not recognized as a legitimate ethnic group with the rights of nationality in Myanmar, future children born to Rohingya parents could be registered as Burmese Muslim people, differentiating themselves from the Rohingya ethnic group. In this regard, there are many Burmese Muslim people around the country who enjoy citizenship rights without discrimination from followers of other religions.

Myanmar will be challenged in deciding how many Rohingya people can be repatriated to Myanmar. Until now, even UNHCR could not enumerate the exact amount of Rohingya people in the world. The most pressing question is who will have responsibility to receive the rest of Rohingya people? The reason this question arises will depend entirely on the Myanmar government's decision. As Myanmar stands in the list of least developed nations in the World Bank Report of 2018, the state will face financial difficulties in repatriating all of the Rohingya people who have left its territory. The Myanmar government should work openly and transparently with allied partners and UN specialised agencies to obtain financial, technical, and humanitarian assistance in the form of a UNHCR global action plan.

After establishing the exact numbers of Rohingya people to be repatriated, the Myanmar government should develop a strategy to carry out repatriation to eradicate the issue of statelessness. The first strategy should address identification or mapping. Stateless Rohingya people are now estimated to be at nearly one million, some of whom seek safety in domestic refugee camps and hundreds of thousands of whom fled to Cox's Bazar. In both Bangladesh and Myanmar, the Rohingya have been excluded even from the assimilation process, effectively cast out of both nations and states. As there may be records of Rohingya people in Myanmar's Immigration offices, returning Rohingya people will be systematically scrutinized upon repatriating. The second strategy is prevention. As Myanmar is experiencing statelessness and human rights crises in border areas, there should be initiative programs to prevent further issues related to statelessness. Rule of law shall serve without any discrimination for both communities in border areas and around the country as well. The other significant strategy is concerned with the reduction of statelessness. This can be done if Myanmar ratifies international human rights instruments on statelessness. Myanmar should be a signatory either to the 1954 Convention relating to the Status of Statelessness or 1961 Convention on the Reduction of Statelessness in order to work with international treaty monitoring bodies. Finally, the state must concern itself with protection. The need to protect against any human rights abuses or violations means that the government must 
provide documentation to Rohingya people for legal safeguards, verification processes to travel, to work, to have health care access and fundamental human rights.

In conclusion, Myanmar, as a country moving towards democracy, should embrace the rule of law as a fundamental, governing legal principle. The current human rights and refugee crises are not only immoral, but dangerous to Myanmar's democracy. There is an urgent need to for the first civilian government to life the state's image, yet it must work on an independent and properly functioning judiciary which is compatible with international principles like jus cogens and erga omnes. As statelessness in Myanmar is created by national laws, this paper strongly recommends that the jus soli principle should be put into Myanmar Citizenship Law.

\section{ACKNOWLEDGEMENT}

First and foremost, I would like to express my deep gratitude to Dr. Elazar Barkan, Director of Institute for the Study of Human Rights (ISHR) at Columbia University, for hosting me in my Fulbright Scholar grant term. I would like to express special thanks to Professor Andrew J. Nathan and Professor Kristina Renee Eberbach from ISHR for their supervision throughout the preparation period of this paper. Most importantly, I would like to convey my honor to Mr. Robert Fabrikant, Professor (Rt.d) of Howard Law School in Washington D.C., US for his valuable manuscript ideas. Last but not least, my sincere thanks go to panel of the Westminster Foundation for Democracy ASIA Academic Seminar of Post Legislative Scrutiny for letting me take participate in seminar with this paper.

\section{BIBLIOGRAPHY}

Andres Bjornberg, Rohingya Territoriality in Myanmar and Bangladesh: Humanitarian Crisis and National Disordering, Myanmar's mountain and maritime borders capes; Local Practices, Boundary-Making and Figured Worlds, ISEAS, 2016.

Alexendra De Mersan, Ritual and the other in Rakhine Spirit Cults, Myanmar's mountain and maritime borders capes; Local Practices, Boundary-Making and Figured Worlds, ISEAS, 2016.

Human Rights Watch: The Rohingya Muslims Ending a Cycle of Exodus? Vol.8, No.9(c), September 1996. https:/www.hrw.org/legacy/summaries/s.burma 969.html\#TOC

Human Rights Watch. (2012). Burma: Satellites Images Show Widespread Attacks on Rohingya.

Kazi Fahmida Farzana, Life along the Naf Border: Identity Politics of the Rohingya Refugees in Bangladesh, Myanmar's mountain and maritime borders capes; Local Practices, Boundary-Making and Figured Worlds, ISEAS, 2016. 
Khin Mg Saw, Geopolitical of the Powers and Bengali Problems in Burma

Ko Swan Sik, Nationality and International Law in Asian Perspective, British Institute of International and Comparative Law Quarterly Journal, Vol-40 (4), (1990), https://doi.org/10.1093/iclqaj/40.4.1004

Laura Van Waas, Nationality Matters; Statelessness under International Law,2008, Intersentia

Maung Aung Myoe, The Maritime Frontier of Myanmar, Myanmar's mountain and maritime borders capes; Local Practices, Boundary-Making and Figured Worlds, ISEAS, 2016

Myanmar Politics and Tatmadaw, Part I, Myawaddy Publishing House, July 2018

Traditional Culture and Traditional Custom, Rakhine, Seit-kuu-chocho Publishing House, $2^{\text {nd }}$ Edition, 2018.

The Lutheran World Federation, An Analysis of Recommendations, April 2016.

UNHCR and IPU, Nationality and Statelessness, A Handbook for Parliamentarians, 2005.

UN, A Study of Statelessness, E/1112, New York, August 1949.

Crimes against Humanity in Western Burma: The Situation of the Rohingya, Irish Center for Human Rights, 2010.

UN News Centre. (2014). Top UN officials call for probe into latest violence in Myanmar's Rakhine state. Retrieved March 15, 2014, from http:// www.un.org/apps/news/story

Williem Van Schendel, History of Bangladesh: Politics, Economic and Civil Society, Cambridge, 2009.

Legislation (Laws/Rules/Orders)

1947 Constitution of the Union of Myanmar

1948 Myanmar Union Citizenship Act

1949 The Residents of Burma Registration Act

1951Residents of Burma Registration Rule

1974 Constitution of the Socialist Republic of the Union of Myanmar

1982 Myanmar Citizenship Law

1989 Myanmar Citizenship Rules

1993 Myanmar Child Law

2008 Constitution of the Republic of the Union of Myanmar

2012 Notification No.58/2012 by Myanmar President's Office on $17^{\text {th }}$ August 
2016 Notification 24/2016 by Myanmar President's Office on 31 ${ }^{\text {st }}$ May 2016, http://www.president-office.gov.mm/en

Order No.75/2017 by President's Office, $12^{\text {th }}$ September 2017

Order No.83/2017 by President's Office, $9^{\text {th }}$ October 2017

Order $86 / 2017$ by the Office of the President on $17^{\text {th }}$ October 2017

Reports

Report of Advisory Commission on Rakhine State: Towards a Peaceful, Fair and Prosperous Future for the People of Rakhine, August 2017

2014 Housing Census and Population Report, Department of Population, Ministry of Immigrant and Population, May 2015

Report on Citizenship Law: Myanmar, Jose Maria Arraiza and Olivier Vonk, Global Citizenship Observatory (GLOBALCIT), RSCAS/GLOBALCIT-CR 2017/14, October 2017

Final Report of Rakhine Inquiry Commission on Sectarian Violence in Rakhine State, $8^{\text {th }}$ July 2013

Report of International Crisis Group, Asia News Agency, 21 ${ }^{\text {st }}$ December 2016,

Special Rapporteur Resolution S-27/1 on $5^{\text {th }}$ December 2017, A/HRC/RES/S-27/1

Report of the Secretary-General on Conflict-Related Sexual Violence, S/2018/250, 16 April 2018, P-28

Report of the People on the Progress of Implementation of the Recommendations on Rakhine State, http://www.president-office.gov.mm/en/?q=issues/rakhinestate-affairs/id-84.57

Report of the Detailed Findings of the Independent International Fact-Finding Mission on Myanmar, A/HRC/39/CRP.2, 39 ${ }^{\text {th }}$ Session of Human Rights Council, $17^{\text {th }}$ September 2018

Resolution of UN General Assembly Third Committee, $73^{\text {rd }}$ Session, $16^{\text {th }}$ November 2018, A/C.3?73/L.51

UN Security Council Report 1992/58

Myanmar National Report for second cycle of Universal Periodic Report 2015

International Conventions

1930 Hague Convention on Certain Questions Relating to the Conflict of Nationality Laws

1948 Universal Declaration of Human Rights

1954 Convention relating to the status of statelessness 
1966 International Covenant on Civil and Political Rights

1989 United Nations Convention on the Rights of the Child

Journals and Newspapers

Asia Time, Anthony Davis, Myanmar's other Rakhine Problem, November 29 2017, http://www.atimes.com/article/myanmars-rakhine-problem/

Global New light of Myanmar www.globalnewlightofmyanmar.com

Refuggees Magazine, Philippe Leclerc and Rupert Colville, In the Shadows, Millions seek to escape the grim world of the stateless, No.147, Issue 3 of 2007

Dr. Su Yin Htun is Assistant Lecturer at the Faculty of Law, Mandalay University, Myanmar. She started her academic career as a tutor at Meiktila University in 2005 and later became an Assistant Lecturer at Taunggyi University. Since 2015 she has been teaching at the University of Mandalay. She received her LLB in 2004, LLM in 2006, and $\mathrm{PhD}$ in 2016. She has participated in various national and international seminars and presented the following papers: "Bilateral Cooperation on Anti-Trafficking in Persons Between the Kingdom of Thailand and the Republic of the Union of Myanmar" (Taunggyi University, 2014); "Social Protection, Health Protection of Mine Workers in Myanmar" (Raoul Wallenberg Institute in Cambodia, 2015); "Legal Protection of Internally Displaced Persons in Myanmar" (Raoul Wallenberg Institute in Lund, Sweden, 2015). At Central European University she is hosted by the Department of Legal Studies where her studies focus on business law and investment relations between China and Myanmar. 